\title{
Predictably irrational: assaying cognitive inflexibility in mouse models of schizophrenia
}

\section{Jonathan L. Brigman*, Carolyn Graybeal and Andrew Holmes}

Section on Behavioral Science and Genetics, Laboratory for Integrative Neuroscience, National Institute on Alcohol Abuse and Alcoholism, NIH, Rockville, MD, USA

The development of sophisticated, translatable mouse-based assays modeling the behavioral manifestations of neuropsychiatric diseases, such as schizophrenia, has lagged the advances in molecular and genomic techniques. Our laboratory has made efforts to fill this gap by investing in the development of novel assays, including adapting a touchscreen-based method for measuring cognitive and executive functions for use in mice. As part of these efforts, a recent study by Brigman et al. (2009) investigated the effects of subchronic phencyclidine treatment on mouse touchscreen-based pairwise visual discrimination and reversal learning. Here, we summarize the results of that study, and place them in the larger context of ongoing efforts to develop valid mouse "models" of schizophrenia, with a focus on reversal learning and other measures of cognitive flexibility. Touchscreen-based systems could provide a tractable platform for fully utilizing the mouse to elucidate the pathophysiology of cognitive inflexibility in schizophrenia and other neuropsychiatric disorders.

Keywords: mouse, schizophrenia, gene, prefrontal cortex, executive function

\section{INTRODUCTION}

The last decade has seen the mouse become one of the model species of choice for researchers studying brain function and neuropsychiatric diseases. This trend has been catalyzed by two key scientific advances during this period: the emergence of techniques for precisely manipulating the mouse genome, such as gene-targeting (Capecchi, 2005), and the sequencing of the human genome (International Human Genome Sequencing Consortium, 2004). In addition, the mouse lends itself to the application of other techniques, both traditional (e.g., drug treatments, brain lesions) and cutting-edge (e.g., RNA interference, opticogenetics), for manipulating molecules, neurotransmitters and circuits in the brain. As such, the mouse-based laboratory is now equipped with a potent armamentarium of techniques to tackle the study of neuropsychiatric disorders. By joining forces with increasingly powerful techniques for studying human subjects, such as genome-wide association studies and brain imaging (Harrison and Weinberger, 2005; Robbins, 2005; Hariri and Holmes, 2006), the hope is that research using mice can allow us to make some truly novel insights into the pathophysiology and treatment of neuropsychiatric diseases, including schizophrenia.

Arguably, the development of sophisticated, translatable mouse-based assays for the behavioral manifestations of schizophrenia has lagged the advances in molecular and genomic techniques. Contrary to a commonly voiced opinion, we do not believe that this is because mice are "not smart enough" to perform complex behavioral, particularly cognitive, assays, but rather that an adequate investment of time and effort has not been put into adapting and validating procedures for the mouse. 


\section{Executive functions}

A collection of higher-order mental processes that exert control over information processing, allowing for the ability to control, adapt and direct behavior in a manner appropriate to current environmental demands. These include, but are not limited to, attention, working memory, behavioral flexibility and inhibition, and decision making. These processes are mediated by a well-conserved neural circuitry, including the prefrontal cortex (PFC) and interconnected subcortical regions, such as the striatum.

\section{Reversal learning}

A measure of cognitive flexibility applicable across species in which subjects first learn a stimulus-reward association, then the reward association is switched. This ostensibly simple process taxes multiple executive functions, including attention, working memory and response inhibition.

Cognitive flexibility

Cognitive flexibility is a critical executive function that can be broadly defined as the ability to adapt behaviors in response to changes in the environment. The Wisconsin Card Sorting Task (WCST) is commonly used to test cognitive flexibility in schizophrenic patients, and analogs have been developed for rodents (e.g., Birrell and Brown "digging task," Birrell and Brown, 2000).
In a collaborative venture with Bussey, Saksida and colleagues, our laboratory has made efforts to fill this gap by investing in the development of novel assays, including adapting a touchscreenbased method for measuring cognitive and executive functions for use in mice (Izquierdo et al., 2006), and by validating existing models of schizophrenia, such as subchronic phencyclidine (PCP) treatment, in the touchscreen system and other mouse assays. We have sought to utilize these assays to elucidate mechanisms subserving complex behaviors and disease-related behavioral dysfunctions. As part of these efforts, we have examined pharmacological models of schizophrenia in our tasks, and recently reported on the effects of subchronic PCP treatment on social behavior and cognition (touchscreen-based visual discrimination and reversal learning) in non-mutant mice (Brigman et al., 2009). Here, we summarize these results and put them in the larger context of ongoing efforts in the field to develop valid models of schizophrenia, or at least assays for some of the main symptoms of the disease, in mice. We begin with a brief overview of how the major symptoms of schizophrenia are clinically categorized and assayed by mouse behav- ioral tests. We go on to discuss in greater detail various mouse assays for "cognitive flexibility", including reversal learning - a type of executive function impaired in schizophrenia that we and others have highlighted as a particularly tractable, translatable process to measure in rodent models of schizophrenia. We end with some concluding remarks on some key questions to be addressed in future work.

\section{MODELING MAJOR SYMPTOM CATEGORIES OF SCHIZOPHRENIA IN MICE}

Schizophrenia is a highly heterogeneous disorder of myriad symptoms. The presentation of different symptoms and their severity varies considerably across patients. While this complexity cannot be fully recapitulated in the mouse, specific symptom categories can be behaviorally modeled in mice. A constructive starting point has been to demarcate schizophrenia-related phenotypes into the clinical categories of positive, negative and cognitive/executive symptoms (Arguello and Gogos, 2006; Powell and Miyakawa, 2006).

Positive symptoms are so-called because theyadd to the normal behavioral repertoire. While a mouse test for hallucinations has not yet been proffered,
A Locomotor response to a novel

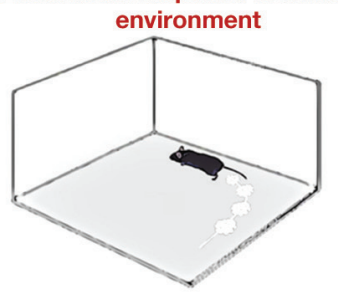

D

Sucrose preference test

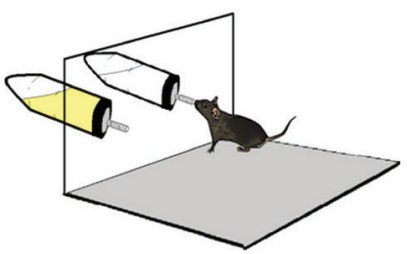

B Locomotor response to psychotomimetic
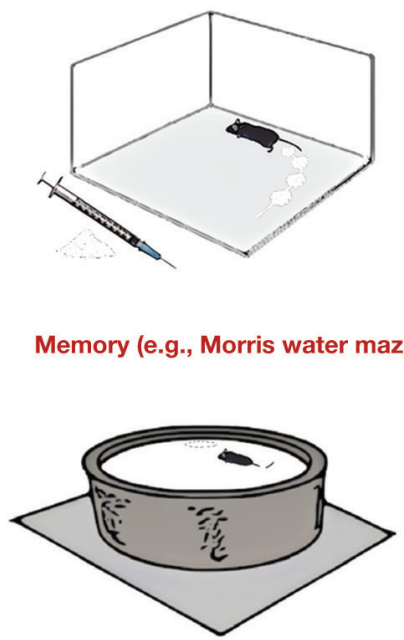

C Social interaction

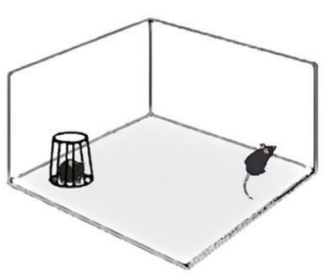

Figure 1 | Mouse behavioral assays for the major symptom categories of schizophrenia. Positive symptoms. The psychomotor agitation and hyper-responsivity to psychotomimetic drugs found in schizophrenia can be modeled in mice by testing locomotor responses in novel and stressful environments $(\mathbf{A})$ and locomotor hyperactivity-inducing effects of psychotomimetics, such as NMDAR antagonists (B), respectively. Negative symptoms. Schizophrenia is often associated with blunted affect, social withdrawal, and loss of pleasure in normally rewarding activities (anhedonia) Social interactions with other mice (C) and decreased preference or motivation to obtain rewarding substances, such as sucrose (D), can be assessed as a means to model these negative symptoms. Cognitive/executive symptoms. Abnormalities in cognition and executive functions are a prominent feature of schizophrenia and range from deficits $i$ n episodic memory, poor attention and sensorimotor gating, to impaired reversal learning and set-shifting. Learning and memory can be tested in mice using, e.g., the reference memory version of the Morris water maze (E), while prepulse inhibition of the startle response provides a ready measure of sensorimotor gating (F). 
other positive symptoms, such as psychomotor agitation and hyper-responsivity to psychotomimetic drugs, can be modeled in mice by testing locomotor responses (particularly under provocative situations, such as stressful environments) (Figure 1A), and locomotor hyperactivity-inducing effects of psychostimulants (e.g., amphetamine) and other psychotomimetics [e.g., $N$-methyl- $\Delta$-aspartate receptor (NMDAR) antagonists dizocilpine/ MK-801 or PCP; Figure 1B].

Rodent models of schizophrenia have traditionally focused on positive symptoms, and this has provided many important mechanistic insights and drug leads. However, there has been a growing emphasis on studying, modeling and treating the negative and cognitive/executive symptoms of the disease (Carter et al., 2008). Negative symptoms (so-called because they subtract from the normal behavioral repertoire) include blunted affect, social withdrawal and loss of pleasure in normally rewarding activities (anhedonia). Various rodent assays for social behavior and anhedonia (e.g., decreased preference or motivation to obtain rewarding substances such as sucrose) have been typically used to model other disorders, such as anxiety (File and Seth, 2003), autism (Crawley, 2004) and depression (Strekalova et al., 2004), but also lend themselves well to the study of abnormalities in these behaviors in models of schizophrenia (Figures 1C,D).

The category of cognitive/executive symptoms covers a range of abnormalities: from deficits in episodic memory to impaired attention and sensorimotor gating. Assays for prepulse inhibition and latent inhibition provide ready measures of sensorimotor gating and selective attention, respectively, that can be applied across species (Figure 1F). Both have been widely employed as a screen for antipsychotics and a measure of schizophrenia-related phenotypes in mutant mice (Feldon and Weiner, 1992; Geyer et al., 2001). There are also numerous very well-studied methods for testing various forms of cognition, such as the spatial reference memory version of the Morris water maze (Figure 1E). However, although impaired episodic memory is one of the strongest features of the cognitive profile of schizophrenia (Ranganath et al., 2008), rodent models of this disease have not relied upon such measures - perhaps because they do not distinguish a model of schizophrenia from other conditions that are also characterized by memory deficits, e.g., Alzheimer's disease.

\section{MOUSE ASSAYS FOR COGNITIVE FLEXIBILITY}

Executive functions subserve the selection and processing of information necessary to plan, control and direct behavior in a manner appropriate to current environmental demands. Across species, these processes are mediated by neural circuitry including the prefrontal cortex (PFC) and interconnected subcortical regions, such as the striatum (Goldman-Rakic, 1996; Miller and Cohen, 2001; Floresco et al., 2009). Pathology in these circuits is a hallmark of schizophrenia (Robbins, 2005; Lewis and Gonzalez-Burgos, 2006; Tan et al., 2009), and is specifically tied to the profound executive deficits exhibited by schizophrenic patients on measures of cognitive flexibility described below.

Cognitive flexibility is a critical executive function that can be broadly defined as the ability to adapt behaviors in response to changes in the environment. The Wisconsin Card Sorting Task (WCST; Grant and Berg, 1948) has been one of the more commonly employed assays for impaired cognitive flexibility in schizophrenic patients, and analogous versions have been developed for use in lower species, including mice (Table 2). In essence, these tasks involve the subject selecting between stimuli, which vary from one another in more than one perceptual dimension (or "set"), and being reinforced for choosing a stimulus based upon one specific dimension alone, e.g., odor. During an "intra-dimensional shift" (IDS), the form of the dimension the subject must choose is changed by the experimenter, e.g., from cinnamon to chocolate odor. In an "extra-dimensional shift" (EDS), the correct dimension is changed altogether, such that choices must be guided by the new dimension (texture) while ignoring the previously rewarded dimension.

In a rodent IDS/EDS analog of the WCST, rats (Birrell and Brown, 2000) or mice (Colacicco et al., 2002; Garner et al., 2006; Bissonette et al., 2008) dig in sand to make choices based on the dimension of texture or smell (Figure 2A). As in humans, this task is sensitive to PFC damage in rats (Birrell and Brown, 2000) and mice (Bissonette et al., 2008). One potentially salient difference with the human procedure is that the dimensions are in different sensory modalities [note: attempts to date to develop a IDS/EDS task using a single (visual) modality have not demonstrated the formation of an attentional set in the mouse (Brigman et al., 2005)].

Reversal learning provides another measure of cognitive flexibility. Subjects first learn a stimulus-reward association, then the reward association is switched. Although reversal learning has been described as hierarchically less complex than set-shifting, it requires flexible switching between cues within the same perceptual dimension or modality, and taxes multiple 
A

Intra-dimensional /

Extra-dimensional digging task
B

Spatial reversal in Morris water maze
C Spatial reversal in T-maze

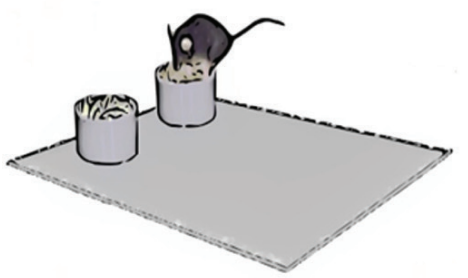

D
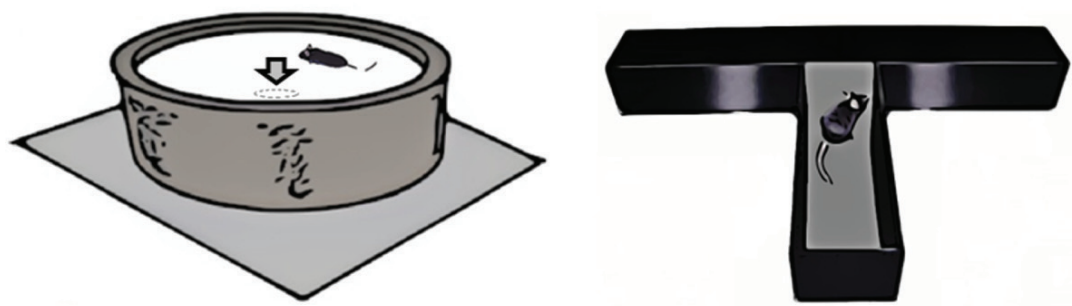

E Reversal of discriminated operant response in touchscreen-based system

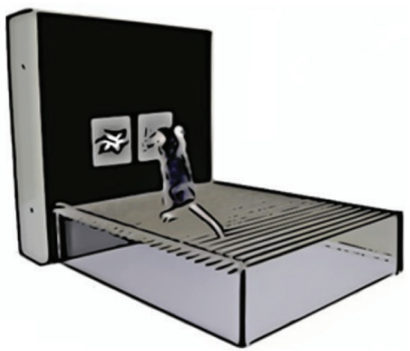

Figure 2 | Mouse behavioral assays for cognitive flexibility.

(A) Intra-dimensional/extra-dimensional digging task. Mice are trained to dig for food reward using either olfactory (digging medium odor) or tactile (digging medium texture) cues. The rewarded cue in the same dimension is switched to test for intra-dimensional shifting. The rewarded cue is changed to the different dimension to test for extra-dimensional shifting. (B) Spatial reversal in Morris water maze. After learning to locate a submerged platform using distal spatial cues (see Figure 1E), the platform location is moved to the opposite side of the pool to test for reversal. (C) Spatial reversal in T-maze. After learning to locate a food reward in one goal arm using distal spatial cues, the rewarded goal arm is switched to test for reversal. (D) Reversal of discriminated operant response in a bar-pressing system. After learning to press a lever for reward based on a visual (e.g., light) or spatial (lever location) cue, the rewarded cue is switched to test for reversal. (E) Reversal of discriminated operant response in a touchscreen-based system. Reversal of a discriminated operant response can also be tested using a touchscreen-based system (for details, see Figure 3).
Touchscreen-based operant system A system in which rats and mice learn to discriminate and reverse between two visual stimuli projected onto a touch-sensitive computer screen. It provides a procedure more analogous and comparable to reversal tasks employed in human subjects. Can be readily modified to test for a battery of cognitive and executive functions. executive functions, including attention, working memory and response inhibition (Roberts, 2006). In addition, reversal learning paradigms allow for a direct measure of perseverative responding to a previously rewarded stimuli or cue, as it is present, but unrewarded, during the reversal phase. This is particularly pertinent because perseveration, possibly caused by insensitivity to negative feedback (i.e., non-reward) following incorrect responding, is a feature of impaired reversal in schizophrenia (Leeson et al., 2009).

\section{TOUCHSCREEN-BASED MEASURE OF REVERSAL LEARNING IN MICE}

Various tasks have been developed to measure reversal in rats and mice in maze (Mackintosh et al., 1968; Ragozzino et al., 1999; Stefani et al., 2003; Floresco et al., 2008) as well as operant settings (e.g., Ferry et al., 2000; Schoenbaum et al., 2000; Bohn et al., 2003a,b; Schoenbaum et al., 2004) (Figures 2B-D). In an effort to provide a procedure that was more analogous and comparable to reversal tasks being employed in patients (Robbins et al., 1994) and higher species (non-human primates), Bussey and colleagues established a touchscreen-based operant system in which rats and mice learn to discriminate and reverse between two visual stimuli projected onto a touch-sensitive computer screen (Bussey et al., 1994, 2001) (Figure 2E). Demonstrating the translatable potential for mapping mouse studies onto systems in the human, reversal performance in this system is PFC-dependent, as confirmed by lesion studies in the rat (Bussey et al., 1997; Chudasama and Robbins, 2003) and to some extent in the mouse (Brigman and Rothblat, 2008).

In addition to its comparability to human measures of reversal, this paradigm has several unique benefits (for discussion, see Bussey et al., 2008). Of note, the automation of the task makes it relatively free of experimenter influences that can vary across individuals and laboratories, and influence results (Crabbe et al., 1999). The sys- 
Subchronic PCP “model” of schizophrenia

Based on the clinical observation that phencyclidine (PCP) and other NMDAR antagonists mimic symptoms of schizophrenia in healthy individuals, Jentsch and Roth (1999) developed a procedure involving repeated treatmen of monkeys and rodents with PCP to produce cognitive deficits and associated prefrontal neurochemical abnormalities. tem is also very flexible and can be easily adapted to test for other forms of cognition and executive function other than discrimination and reversal, such as extinction (Hefner et al., 2008), spatial paired-associate learning (associating an object with a spatial location) (Talpos et al., 2009) and pattern separation (discrimination of perceptually similar stimuli) (Clelland et al., 2009).

In our formulation of the task (Izquierdo et al., 2006; Brigman et al., 2008) (Figure 3), mice are first trained to initiate the appearance of the stimuli on-screen by a head entry into a magazine where food pellets are delivered (Figure 3A). There is then some training to shape the mouse to touch the screen to obtain reward before discrimination learning begins (Figure 3B). Discrimination is typically between two (i.e., pairwise) distinct visual stimuli, with responses on one stimulus rewarded with food and responses on the other producing a timeout period during which additional responses cannot be made (Figure 3C). After reaching a predetermined criterion of discrimination (e.g., $>85 \%$ correct choices), the stimulus-reward contingencies are reversed and the subject must inhibit perseverative responses to the previously rewarded stimulus and learn to respond to the alternate, previously unrewarded, stimulus (Figure 3D).

The capacity for this system to concurrently assess discrimination as well as reversal learning provides an excellent internal control, not only for learning and behavioral performance generally, but also because discrimination is impaired in some cases of schizophrenia. For example, discrimination and reversal learning were significantly impaired in chronic hospitalized schizophrenic patients with frontal lobe damage (Pantelis et al., 1999). Interestingly, more stabilized patients were found to be more specifically impaired on reversal and EDS shifts (Elliott et al., 1995; Waltz and Gold, 2007) and some first-episode schizophrenics exhibited even more restricted, EDS-only, impairment (Hutton et al., 1998; Joyce et al., 2002; Braw et al., 2008). These findings raise the interesting possibility that the profile of discrimination/reversal/setshifting impairment may be graded in a manner corresponding to the chronicity of schizophrenia (Joyce et al., 2002). On the other hand, there are clinical data showing clear deficits in both reversal and set-shifting in first-episode schizophrenics, and especially in those patients with prominent thought disorganization symptoms (Barnett et al., 2005; Murray et al., 2008; Leeson et al., 2009). One interpretation of these findings is that the breadth and pattern of deficits in discrimination/reversal/set-shifting may be more of a marker for specific subtypes of the disease rather than of disease severity (Leeson et al., 2009). The touchscreen procedure could prove to be valuable for delineating discrimination and reversal impairments in mouse models, and thereby shed light on the pathophysiology underlying their dissociation in different subpopulations of schizophrenic patients.

\section{EFFECTS OF SUBCHRONIC PCP TREATMENT ON DISCRIMINATION AND REVERSAL}

There is compelling evidence implicating the glutamate system in the pathophysiology of schizophrenia (Coyle, 2006). As part of a larger

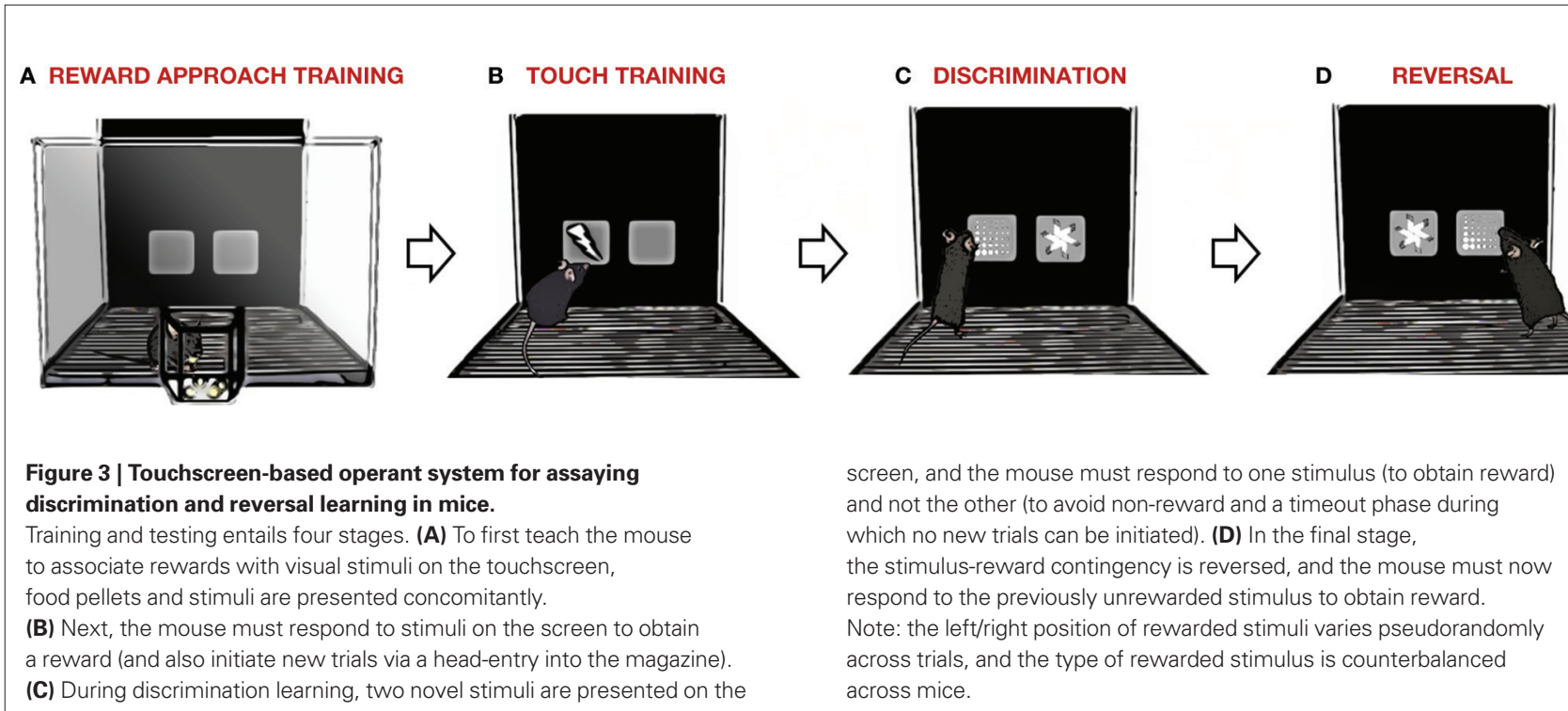


research program to elucidate the role of glutamate in cognitive and executive functions, we have studied the effects of null mutations in various components of the glutamate system on the touchscreen-based method (Brigman et al., 2008; Karlsson et al., 2008; Wiedholz et al., 2008; Karlsson et al., 2009). To compliment and extend these studies, we (Brigman et al., 2009) investigated a pharmacological model of glutamatergic dysfunction in schizophrenia - subchronic PCP treatment.

PCP and other NMDAR antagonists (e.g., ketamine) mimic positive and negative symptoms of schizophrenia in otherwise healthy individuals (Javitt and Zukin, 1991; Krystal et al., 1994). Based upon this observation, Jentsch and colleagues subchronically treated monkeys and rats with PCP and found cognitive deficits and associated prefrontal neurochemical abnormalities (reviewed in Jentsch and Roth, 1999). The subchronic PCP model has since been quite widely employed as a rodent model for executive dysfunctions in schizophrenia.

In order to test the subchronic PCP model in the touchscreen-based assay, Brigman et al. (2009) treated C57BL/6J mice with $5 \mathrm{mg} / \mathrm{kg}$ PCP twice daily for 7 days and, after a 7-day withdrawal period, tested for discrimination and (in a separate group of mice) reversal in the touchscreen-based task. This treatment and withdrawal duration was based on previous work by Jentsch et al. (1997a). Results showed no significant impairments in drug-treated mice in comparison to vehicle treated controls on either discrimination or reversal, as measured using a range of dependent variables. By con- trast, the same treatment regimen that failed to affect discrimination or reversal was sufficient to reduce social behavior - demonstrating that treatment was sufficient to mimic some symptoms of schizophrenia.

While Brigman et al. (2009) was the first study of the PCP model in a rodent touchscreen-based procedure, the lack of impairment may appear somewhat surprising, given PCP-induced deficits have been found on other measures of reversal in rats and mice (summarized in Table 1). However, similar to Brigman et al., negative effects on reversal have also been reported (including in studies in which there are clear PCP-induced deficits in the EDS component, e.g., Rodefer et al., 2005, 2008; Egerton et al., 2008). Direct comparisons between studies are further complicated by variations in treatment regimen and methodology. For example, while Neill and colleagues (Abdul-Monim et al., 2006, 2007) have demonstrated reversal impairments in a light-cue based operant task in rats subjected to a PCP treatment and withdrawal procedure comparable to Brigman et al., their task required subjects to completely inhibit responses on some trials to obtain reward, which likely placed greater demands on inhibitory control than the task used by Brigman et al. (in which a response was always available). This is likely a salient difference because subchronic PCP treatment impairs inhibitory control in rats and non-human primates (Jentsch et al., 1997b, 2000; Jentsch and Taylor, 2001). Clearly, further work is needed to parse the most critical features of reversal assays that render them sensitive to subchronic PCP treatment.

\begin{tabular}{llll}
\hline Table $\mathbf{1}$ | Studies on the effects of acute and chronic PCP treatment on measures of cognitive flexibility. & \\
\hline Species & Assay (stimulus modality) & PCP treatment regimen (dose) & Reference \\
\hline & & & \\
Rat & Operant reversal (visual) & Acute $(1.0-1.5 \mathrm{mg} / \mathrm{kg})$ & Abdul-Monim et al. (2003) \\
Rat & Operant reversal (visual) & Acute $(1.5-2.0 \mathrm{mg} / \mathrm{kg})$ & Idris et al. (2005) \\
Rat & Operant reversal (visual) & Chronic, daily $(2 \mathrm{mg} / \mathrm{kg}) \times 7$ days, +7 days w/d & Abdul-Monim et al. (2006) \\
Rat & Operant reversal (visual) & Chronic, daily $(2 \mathrm{mg} / \mathrm{kg}) \times 7$ days, +7 days w/d & Abdul-Monim et al. (2007) \\
Mouse & Operant reversal (visual) & Chronic, twice daily $(5 \mathrm{mg} / \mathrm{kg}) \times 7$ days, +7 days w/d & Brigman et al. (2009) \\
Rat & Spatial reversal (visual) & Chronic, twice daily $(5 \mathrm{mg} / \mathrm{kg}) \times 7$ days, +7 days w/d & Jentsch and Taylor (2001) \\
Rat & IDS/EDS (tactile/olfactory) & Acute $(2.58 \mathrm{mg} / \mathrm{kg})$ & Egerton et al. (2005) \\
Rat & IDS/EDS (tactile/olfactory) & Repeated $(10-20 \mathrm{mg} / \mathrm{kg})$ on postnatal days P7, 9, 11 & Broberg et al. (2008) \\
Rat & IDS/EDS (tactile/olfactory) & Chronic, daily $(2.6 \mathrm{mg} / \mathrm{kg}) \times 5$ days, +3 days w/d & Egerton et al. (2008) \\
Mouse & IDS/EDS (tactile/olfactory) & Chronic, daily $(0.63-1.3 \mathrm{mg} / \mathrm{kg}) \times 10$ days & Laurent and Podhorna (2004) \\
Rat & IDS/EDS (tactile/olfactory) & Chronic, twice daily $(5 \mathrm{mg} / \mathrm{kg}) \times 7$ days, +10 days w/d & Rodefer et al. (2005) \\
Rat & IDS/EDS (tactile/olfactory) & Chronic, twice daily $(5 \mathrm{mg} / \mathrm{kg}) \times 7$ days, +10 days w/d & Rodefer et al. (2008) \\
Monkey & Detour reaching task & Chronic, twice daily $(0.3 \mathrm{mg} / \mathrm{kg}) \times 14$ days, +7 days w/d & Jentsch et al. (1997a)
\end{tabular}

IDS/EDS, intra-dimensional/extra-dimensional set shifting; w/d, withdrawal period prior to testing 


\section{CONCLUDING REMARKS}

The Brigman et al. data raise some interesting questions for further studies examining the effects of subchronic PCP on reversal in the touchscreen system. For example, would increasing the difficulty of the reversal (e.g., by increasing the perceptual similarity of the visual stimuli), presenting distracters, or making reinforcement probabilistic, increase the sensitivity of the assay to PCP treatment? Such task-dependent effects would be intriguing, given the aforementioned clinical data hinting that the range of executive deficits may increase in tandem with disease chronicity and severity. In this context, another interesting course would be to parametrically vary dose and/or chronicity of treatment to ask whether more "intensive" treatment regimens produced significant reversal deficits. Beyond the subchronic PCP model, the touchscreen-based system has great potential for evaluating mouse models of schizophrenia

Table 2 | Examples of studies of cognitive flexibility in mutant mice.

\begin{tabular}{|c|c|c|c|}
\hline Assay & Mutant & Reversal effect & Reference \\
\hline IDS/EDS & Hdh CAC(150) knock-in & Impaired & Brooks et al. (2006) \\
\hline IDS/EDS & Dopamine D3 receptor knockout & Facilitated & Glickstein et al. (2005) \\
\hline IDS/EDS & COMT-Val transgenic & None & Papaleo et al. (2008) \\
\hline IDS/EDS & Tg2576 APP Swedish mutation & Impaired & Zhuo et al. (2007) \\
\hline MWM & Vesicular glutamate transporter deficient & Impaired & Balschun et al. (2009) \\
\hline MWM & $N$-terminal amidase deficient & Facilitated & Balogh et al. (2001) \\
\hline MWM & Ins2 $2^{\mathrm{C} 96 \mathrm{Y}}$ Akita & None & Choeiri et al. (2005) \\
\hline MWM & Rac3 knockout & Impaired & Corbetta et al. (2008) \\
\hline MWM & TgCRND8 APP double mutant & Impaired & Chishti et al. (2001) \\
\hline MWM & Synaptic vesicle protein (Rab3a) deficient & Impaired & D'Adamo et al. (2004) \\
\hline MWM & mGluR4 deficient & Facilitated & Gerlai et al. (1998) \\
\hline MWM & $\alpha 3-G A B A_{a}$ deficient & Trend for impaired & Fiorelli et al. (2008) \\
\hline MWM & PS1 transgenic, L235P mutation & None & Huang et al. (2003) \\
\hline MWM & $\beta$-amyloid precursor protein transgenic & Impaired & Koistinaho et al. (2001) \\
\hline MWM & D-amino acid oxidase deficient & Facilitated & Labrie et al. (2009) \\
\hline MWM & Presenilin 1 knockout & Rescues APP transgenic & Saura et al. (2005) \\
\hline MWM & Protein tyrosine phosphatase-alpha deficient & None & Skelton et al. (2003) \\
\hline MWM & Offspring of vasoactive intestinal peptide deficient dams & Impaired & Stack et al. (2008) \\
\hline MWM & Guanine nucleotide exchange factor (Ric-8) deficient & Impaired & Tonissoo et al. (2006) \\
\hline MWM & CB1 endocannabinoid receptor deficient & Impaired & Varvel and Lichtman (2002) \\
\hline MWM & GDNF receptor $\alpha 2$ deficient & Impaired & Voikar et al. (2004) \\
\hline Spatial & APP/PS1 transgenic & Age-related impairment & Filali and Lalonde (2009) \\
\hline Spatial & Ts65Dn cholinergic deficient Down's model & Impaired & Granholm et al. (2000) \\
\hline Spatial & DARPP-32 knockout & Impaired & Heyser et al. (2000) \\
\hline Spatial & PEPCK bGH transgenic elevated growth hormone & Facilitated & Meliska et al. (1997) \\
\hline Spatial & APP/PS1 transgenic Alzheimer's model & None & O'Leary and Brown (2009) \\
\hline Spatial & AMPA receptor subunit (GluRA) knockout & Impaired & Schmitt et al. (2004) \\
\hline
\end{tabular}

IDS/EDS, intra-dimensional/extra-dimensional shifting task; MWM, Morris water maze. 
and, indeed, for other neuropsychiatric disorders characterized by cognitive inflexibility and other executive dysfunctions, such as depression (Holmes and Wellman, 2009) and drug addiction (Schoenbaum and Shaham, 2008). In concert with more established assays described above, the system could provide a valuable behavioral platform for elucidating the aberrant neural, molecular and genetic mechanisms underlying cognitive inflexibility in these disorders.

\section{ACKNOWLEDGMENTS}

We are grateful to Dr. Timothy J. Bussey for comments on the manuscript. Research supported by the Intramural Research Programs of the National Institute on Alcohol Abuse and Alcoholism (Z01-AA000411).

\section{REFERENCES}

Abdul-Monim, Z., Neill, J. C., and Reynolds, G. P. (2007). Sub-chronic psychotomimetic phencyclidine induces deficits in reversal learning and alterations in parvalbuminimmunoreactive expression in the rat. J. Psychopharmacol. 21, 198-205.

Abdul-Monim, Z., Reynolds, G. P., and Neill, J. C. (2003). The atypical antipsychotic ziprasidone, but not haloperidol, improves phencyclidine-induced cognitive deficits in a reversal learning task in the rat. J. Psychopharmacol. 17, 57-65.

Abdul-Monim, Z., Reynolds, G. P., and Neill, J. C. (2006). The effect of atypical and classical antipsychotics on sub-chronic PCP-induced cognitive deficits in a reversal-learning paradigm. Behav. Brain Res. 169, 263-273.

Angelo, M., Plattner, F., Irvine, E. E., and Giese, K. P. (2003). Improved reversal learning and altered fear conditioning in transgenic mice with regionally restricted p25 expression. Eur. J. Neurosci. 18, 423-431.

Arguello, P. A., and Gogos, J. A. (2006). Modeling madness in mice: one piece at a time. Neuron 52, 179-196.

Balogh, S. A., McDowell, C. S., Tae Kwon, Y., and Denenberg, V. H. (2001). Facilitated stimulus-response associative learning and long-term memory in mice lacking the NTAN1 amidase of the N-end rule pathway. Brain Res. 892, 336-343.

Balschun, D., Moechars, D., CallaertsVegh,Z., Vermaercke, B., Van Acker, N., Andries, L., and D'Hooge, R. (2009). Vesicular glutamate transporter VGLUT1 has a role in hippocampal long-term potentiation and spatial reversal learning. Cereb. Cortex. doi: 10.1093/cercor/bhp133.

Bannerman, D. M., Deacon, R. M., Seeburg, P. H., and Rawlins, J. N. (2003). GluR-A-deficient mice display normal acquisition of a hippocampusdependent spatial reference memory task but are impaired during spatial reversal. Behav. Neurosci. 117, 866-870.

Barnett, J. H., Sahakian, B. J., Werners, U., Hill, K. E., Brazil, R., Gallagher,
O., Bullmore, E. T., and Jones, P. B. (2005). Visuospatial learning and executive function are independently impaired in first-episode psychosis. Psychol. Med. 35, 1031-1041.

Birrell, J. M., and Brown, V. J. (2000). Medial frontal cortex mediates perceptual attentional set shifting in the rat. J. Neurosci. 20, 4320-4324.

Bissonette, G. B., Martins, G. J., Franz, T. M., Harper, E. S., Schoenbaum, G. and Powell, E. M. (2008). Double dissociation of the effects of medial and orbital prefrontal cortical lesions on attentional and affective shifts in mice. J. Neurosci. 28, 11124-11130.

Bohn, I., Giertler, C., and Hauber, W. (2003a). NMDA receptors in the rat orbital prefrontal cortex are involved in guidance of instrumental behaviour under reversal conditions. Cereb. Cortex 13, 968-976.

Bohn, I., Giertler, C., and Hauber, W. (2003b). Orbital prefrontal cortex and guidance of instrumental behaviour in rats under reversal conditions. Behav. Brain Res. 143, 49-56.

Braw, Y., Bloch, Y., Mendelovich, S., Ratzoni, G., Gal, G., Harari, H., Tripto A., and Levkovitz, Y. (2008). Cognition in young schizophrenia outpatients: comparison of first-episode with multiepisode patients. Schizophr. Bull. 34, 544-554.

Brigman, J. L., Bussey, T. J., Saksida, L. M., and Rothblat, L. A. (2005). Discrimination of multidimensional visual stimuli by mice: intra- and extradimensional shifts. Behav. Neurosci. 119, 839-842.

Brigman, J. L., Feyder, M., Saksida, L. M. Bussey, T. J., Mishina, M., and Holmes, A. (2008). Impaired discrimination learning in mice lacking the NMDA receptor NR2A subunit. Learn. Mem. $15,50-54$

Brigman, J. L., Ihne, J., Saksida, L. M., Bussey, T. J., and Holmes, A. (2009). Effects of subchronic phencyclidine (PCP) treatment on social behaviors, and operant discrimination and reversal learning in C57BL/6 J mice. Front. Behav. Neurosci. 3:2. doi:10.3389/neuro.08.002.2009.

Brigman, J. L., Padukiewicz, K. E., Sutherland, M. L., and Rothblat, L.
A. (2006). Executive functions in the heterozygous reeler mouse model of schizophrenia. Behav. Neurosci. 120, 984-988.

Brigman, J. L., and Rothblat, L. A. (2008). Stimulus specific deficit on visual reversal learning after lesions of medial prefrontal cortex in the mouse. Behav. Brain Res. 187, 405-410.

Broberg, B. V., Dias, R., Glenthoj, B. Y., and Olsen, C. K. (2008). Evaluation of a neurodevelopmental model of schizophrenia - early postnatal PCP treatment in attentional set-shifting. Behav. Brain Res. 190, 160-163.

Brooks, S. P., Betteridge, H., Trueman, R. C., Jones, L., and Dunnett, S. B. (2006). Selective extra-dimensional set shifting deficit in a knock-in mouse model of Huntington's disease. Brain Res. Bull. 69, 452-457.

Bussey, T. J., Muir, J. L., Everitt, B. J., and Robbins, T.W. (1997). Triple dissociation of anterior cingulate, posterior cingulate, and medial frontal cortices on visual discrimination tasks using a touchscreen testing procedure for the rat. Behav. Neurosci. 111, 920-936.

Bussey, T. J., Muir, J. L., and Robbins, T. W. (1994). A novel automated touchscreen procedure for assessing learning in the rat using computer-graphic stimuli. Neurosci. Res. Commun. 15 103-110.

Bussey, T. J., Padain, T. L., Skillings, E. A., Winters, B. D., Morton, A. J., and Saksida, L. M. (2008). The touchscreen cognitive testing method for rodents: how to get the best out of your rat. Learn. Mem. 15, 516-523.

Bussey, T. J., Saksida, L. M., and Rothblat, L. A. (2001). Discrimination of computer-graphic stimuli by mice: a method for the behavioral characterization of transgenic and gene-knockout models. Behav. Neurosci. 115, 957-960.

Capecchi, M. R. (2005). Gene targeting in mice: functional analysis of the mammalian genome for the twenty-first century. Nat. Rev. Genet. 6, 507-512.

Carter, C. S., Barch, D. M., Buchanan, R. W., Bullmore, E., Krystal, J.H., Cohen, J., Geyer, M., Green, M., Nuechterlein, K. H., Robbins, T., Silverstein, S., Smith, E. E., Strauss, M., Wykes, T., and Heinssen, R. (2008). Identifying cognitive mechanisms targeted for treatment development in schizophrenia: an overview of the first meeting of the Cognitive Neuroscience Treatment Research to Improve Cognition in Schizophrenia Initiative. Biol. Psychiatry 64, 4-10.

Chishti, M. A., Yang, D. S., Janus, C., Phinney, A. L., Horne, P., Pearson, J., Strome, R., Zuker, N., Loukides, J., French, J., Turner, S., Lozza, G., Grilli, M., Kunicki, S., Morissette, C., Paquette, J., Gervais, F., Bergeron, C., Fraser, P. E., Carlson, G. A., GeorgeHyslop, P. S., and Westaway, D. (2001). Early-onset amyloid deposition and cognitive deficits in transgenic mice expressing a double mutant form of amyloid precursor protein 695. J. Biol. Chem. 276, 21562-21570.

Choeiri, C., Hewitt, K., Durkin, J., Simard, C. J., Renaud, J. M., and Messier, C. (2005). Longitudinal evaluation of memory performance and peripheral neuropathy in the Ins2C96Y Akita mice. Behav. Brain Res. 157, 31-38.

Chudasama, Y., and Robbins, T.W. (2003). Dissociable contributions of the orbitofrontal and infralimbic cortex to pavlovian autoshaping and discrimination reversal learning: further evidence for the functional heterogeneity of the rodent frontal cortex. J. Neurosci. 23, 8771-8780.

Clelland, C. D., Choi, M., Romberg, C., Clemenson, G. D. Jr., Fragniere, A., Tyers, P., Jessberger, S., Saksida, L. M., Barker, R. A., Gage, F. H., and Bussey, T. J. (2009). A functional role for adult hippocampal neurogenesis in spatial pattern separation. Science 325, 210-213.

Colacicco, G., Welzl, H., Lipp, H. P., and Wurbel, H. (2002). Attentional setshifting in mice: modification of a rat paradigm, and evidence for straindependent variation. Behav. Brain Res. 132, 95-102.

Corbetta, S., D’Adamo, P., Gualdoni, S., Braschi, C., Berardi, N., and de Curtis, I. (2008). Hyperactivity and novelty-induced hyperreactivity in mice lacking Rac3. Behav. Brain Res. 186, 246-255.

Coyle, J. T. (2006). Glutamate and schizophrenia: beyond the dopamine 
hypothesis. Cell. Mol. Neurobiol. 26, 365-384.

Crabbe, J. C., Wahlsten, D., and Dudek, B. C. (1999). Genetics of mouse behavior: interactions with laboratory environment. Science 284, 1670-1672.

Crawley, J. N. (2004). Designing mouse behavioral tasks relevant to autisticlike behaviors. Ment. Retard Dev. Disabil. Res. Rev. 10, 248-258.

D’Adamo, P., Wolfer, D. P., Kopp, C., Tobler, I., Toniolo, D., and Lipp, H. P. (2004). Mice deficient for the synaptic vesicle protein Rab3a show impaired spatial reversal learning and increased explorative activity but none of the behavioral changes shown by mice deficient for the Rab3a regulator Gdil. Eur. J. Neurosci. 19, 1895-1905.

Dawson, D. A., Grant, B. F., and Ruan, W. J. (2005). The association between stress and drinking: modifying effects of gender and vulnerability. Alcohol Alcohol. 40, 453-460.

De Steno, D. A., and Schmauss, C. (2009). A role for dopamine D2 receptors in reversal learning. Neuroscience 162, 118-127.

Egerton, A., Reid, L., McGregor, S., Cochran, S. M., Morris, B. J., and Pratt, J. A. (2008). Subchronic and chronic PCP treatment produces temporally distinct deficits in attentional set shifting and prepulse inhibition in rats. Psychopharmacology (Berl.) 198, 37-49.

Egerton, A., Reid, L., McKerchar, C. E., Morris, B. J., and Pratt, J. A. (2005). Impairment in perceptual attentional set-shifting following PCP administration: a rodent model of set-shifting deficits in schizophrenia. Psychopharmacology (Berl.) 179, 77-84.

Ehrman, L.A., Williams, M. T., Schaefer, T. L., Gudelsky, G.A., Reed,T.M.,Fienberg, A. A., Greengard, P., and Vorhees, C. V. (2006). Phosphodiesterase 1B differentially modulates the effects of methamphetamine on locomotor activity and spatial learning through DARPP32-dependent pathways: evidence from PDE1B-DARPP32 double-knockout mice. Genes Brain Behav. 5, 540-551.

Elias, M. F., and Eleftheriou, B. E. (1972). Reversal learning and RNA labeling in neurological mutant mice and normal littermates. Physiol. Behav. 9, 27-34.

Elliott, R., McKenna, P. J., Robbins, T. W., and Sahakian, B. J. (1995). Neuropsychological evidence for frontostriatal dysfunction in schizophrenia. Psychol. Med. 25, 619-630.

Feldon, J., and Weiner, I. (1992). From an animal model of an attentional deficit towards new insights into the pathophysiology of schizophrenia. J. Psychiatr. Res. 26, 345-366.
Ferry, A. T., Lu, X. C., and Price, J. L. (2000). Effects of excitotoxic lesions in the ventral striatopallidal-thalamocortical pathway on odor reversal learning: inability to extinguish an incorrect response. Exp. Brain Res. 131, 320-335.

Filali, M., and Lalonde, R. (2009). Agerelated cognitive decline and nesting behavior in an APPswe/PS1 bigenic model of Alzheimer's disease. Brain Res. 1292, 93-99.

File, S. E., and Seth, P. (2003). A review of 25 years of the social interaction test. Eur. J. Pharmacol. 463, 35-53.

Fiorelli, R., Rudolph, U., Straub, C. J., Feldon, J., and Yee, B. K. (2008). Affective and cognitive effects of global deletion of alpha3-containing gammaaminobutyric acid-A receptors. Behav Pharmacol 19, 582-596.

Floresco, S. B., Block, A. E., and Tse, M. T. (2008). Inactivation of the medial prefrontal cortex of the rat impairs strategy set-shifting, but not reversal learning, using a novel, automated procedure. Behav. Brain Res. 190, 85-96.

Floresco, S. B., Zhang, Y., and Enomoto, T. (2009). Neural circuits subserving behavioral flexibility and their relevance to schizophrenia. Behav. Brain Res. 204, 396-409.

Garner, J. P., Thogerson, C. M., Wurbel, H., Murray, J. D., and Mench, J. A. (2006). Animal neuropsychology: validation of the Intra-Dimensional Extra-Dimensional set shifting task for mice. Behav. Brain Res. 173, 53-61.

Gass, P., Wolfer, D. P., Balschun, D. Rudolph, D., Frey, U., Lipp, H. P., and Schutz, G. (1998). Deficits in memory tasks of mice with CREB mutations depend on gene dosage. Learn. Mem. 5, 274-288.

Gerlai, R., Roder, J. C., and Hampson, D. R. (1998). Altered spatial learning and memory in mice lacking the mGluR4 subtype of metabotropic glutamate receptor. Behav. Neurosci. 112, 525-532.

Geyer, M. A., Krebs-Thomson, K., Braff, D. L., and Swerdlow, N. R. (2001). Pharmacological studies of prepulse inhibition models of sensorimotor gating deficits in schizophrenia: a decade in review. Psychopharmacology (Berl.) 156, 117-154.

Glickstein, S. B., Desteno, D. A., Hof, P. R., and Schmauss, C. (2005). Mice lacking dopamine D2 and D3 receptors exhibit differential activation of prefrontal cortical neurons during tasks requiring attention. Cereb. Cortex 15 , 1016-1024.

Goldman-Rakic, P.S. (1996). The prefrontal landscape: implications of functional architecture for understanding human mentation and the central executive. Philos. Trans. R. Soc. Lond. B, Biol. Sci. 351, 1445-1453.

Granholm,A.C., Sanders, L.A., and Crnic, L. S. (2000). Loss of cholinergic phenotype in basal forebrain coincides with cognitive decline in a mouse model of Down's syndrome. Exp. Neurol. 161, 647-663.

Grant, D. A., and Berg, E. A. (1948). A behavioral analysis of degree of reinforcement and ease of shifting to new responses in a Weigl-type card-sorting problem. J. Exp. Psychol. 38, 404-411.

Hariri, A. R., and Holmes, A. (2006). Genetics of emotional regulation: the role of the serotonin transporter in neural function. Trends Cogn. Sci. 10, 182-191.

Harrison, P. J., and Weinberger, D. R. (2005). Schizophrenia genes, gene expression, and neuropathology: on the matter of their convergence. Mol Psychiatry 10, 40-68.

Hefner, K., Whittle, N., Juhasz, J., Norcross, M., Karlsson, R. M., Saksida L. M., Bussey, T. J., Singewald, N., and Holmes, A. (2008). Impaired fear extinction learning and cortico-amygdala circuit abnormalities in a common genetic mouse strain. J. Neurosci. $28,8074-8085$.

Heyser, C. J., Fienberg, A. A., Greengard P., and Gold, L. H. (2000). DARPP32 knockout mice exhibit impaired reversal learning in a discriminated operant task. Brain Res. 867, 122-130.

Holmes, A., and Wellman, C. L. (2009). Stress-induced prefrontal reorganization and executive dysfunction in rodents. Neurosci. Biobehav. Rev. 33 773-783.

Huang, X. G., Yee, B. K., Nag, S., Chan, S. T., and Tang, F. (2003). Behavioral and neurochemical characterization of transgenic mice carrying the human presenilin-1 gene with or without the leucine-to-proline mutation at codon 235. Exp. Neurol. 183, 673-681.

Hutton, S. B., Puri, B. K., Duncan, L. J. Robbins, T.W., Barnes, T. R., and Joyce, E. M. (1998). Executive function in first-episode schizophrenia. Psychol. Med. 28, 463-473.

Idris, N. F., Repeto, P., Neill, J. C., and Large, C. H. (2005). Investigation of the effects of lamotrigine and clozapine in improving reversal-learning impairments induced by acute phencyclidine and D-amphetamine in the rat. Psychopharmacology (Berl.) 179 , 336-348.

InternationalHuman GenomeSequencing Consortium. (2004). Finishing the euchromatic sequence of the human genome. Nature 431, 931-945.

Izquierdo, A., Wiedholz, L. M., Millstein, R. A., Yang, R. J., Bussey, T. J., Saksida, L. M., and Holmes, A. (2006). Genetic and dopaminergic modulation of reversal learning in a touchscreenbased operant procedure for mice. Behav. Brain Res. 171, 181-188.

Javitt, D. C., and Zukin, S. R. (1991). Recent advances in the phencyclidine model of schizophrenia. Am. J. Psychiatry 148, 1301-1308.

Jentsch, J. D., Redmond, D.E. Jr., Elsworth, J. D., Taylor, J. R., Youngren, K. D., and Roth, R. H. (1997a). Enduring cognitive deficits and cortical dopamine dysfunction in monkeys after longterm administration of phencyclidine. Science 277, 953-955.

Jentsch, J. D., Tran, A., Le, D., Youngren, K. D., and Roth, R. H. (1997b). Subchronic phencyclidine administration reduces mesoprefrontal dopamine utilization and impairs prefrontal cortical-dependent cognition in the rat. Neuropsychopharmacology 17, 92-99.

Jentsch, J. D., and Roth, R. H. (1999). The neuropsychopharmacology of phencyclidine: from NMDA receptor hypofunction to the dopamine hypothesis of schizophrenia. Neuropsychopharmacology 20, 201-225.

Jentsch, J. D., Roth, R. H., and Taylor, J. R. (2000). Object retrieval/detour deficits in monkeys produced by prior subchronic phencyclidine administration: evidence for cognitive impulsivity. Biol. Psychiatry 48, 415-424.

Jentsch, J. D., and Taylor, J. R. (2001). Impaired inhibition of conditioned responses produced by subchronic administration of phencyclidine to rats. Neuropsychopharmacology 24 66-74.

Joyce, E., Hutton, S., Mutsatsa, S., Gibbins, H., Webb, E., Paul, S., Robbins, T., and Barnes, T. (2002). Executive dysfunction in first-episode schizophrenia and relationship to duration of untreated psychosis: the West London Study. Br. J. Psychiatry Suppl. 43, s38-s44.

Karlsson, R. M., Tanaka, K., Heilig, M., and Holmes, A. (2008). Loss of glial glutamate and aspartate transporter (excitatory amino acid transporter 1) causes locomotor hyperactivity and exaggerated responses to psychotomimetics: rescue by haloperidol and metabotropic glutamate $2 / 3$ agonist Biol. Psychiatry 64, 810-814.

Karlsson, R. M., Tanaka, K., Saksida, L. M., Bussey, T. J., Heilig, M., and Holmes, A. (2009). Assessment of glutamate transporter GLAST (EAAT1)deficient mice for phenotypes relevant to the negative and executive/ cognitive symptoms of schizophrenia. Neuropsychopharmacology 34 1578-1589.

Kofman, O., Shavit, Y., Ashkenazi, S., and Gabay, S. (2007). Habituation, 
discrimination and anxiety in transgenic mice overexpressing acetylcholinesterase splice variants. Brain Res. $1185,170-178$

Koistinaho, M., Ort, M., Cimadevilla, J. M., Vondrous, R., Cordell, B., Koistinaho, J., Bures, J., and Higgins, L. S. (2001) Specific spatial learning deficits become severe with age in beta-amyloid precursor protein transgenic mice that harbor diffuse beta-amyloid deposits but do not form plaques. Proc. Natl. Acad. Sci. U.S.A. 98, 14675-14680.

Krueger, D. D., Howell, J. L., Hebert, B. F. Olausson, P., Taylor, J. R., and Nairn, A. C. (2006). Assessment of cognitive function in the heterozygous reeler mouse. Psychopharmacology (Berl.) 189, 95-104.

Kruzich, P. J., Mitchell, S. H., Younkin, A., and Grandy, D. K. (2006). Dopamine $\mathrm{D} 2$ receptors mediate reversal learning in male C57BL/6J mice. Cogn. Affect. Behav. Neurosci. 6, 86-90.

Krystal, J. H., Karper, L. P., Seibyl, J. P., Freeman, G. K., Delaney, R., Bremner, J. D., Heninger, G. R., Bowers, M. B. Jr., and Charney, D.S. (1994). Subanesthetic effects of the noncompetitive NMDA antagonist, ketamine, in humans. Psychotomimetic, perceptual, cognitive, and neuroendocrine responses. Arch. Gen. Psychiatry. 51, 199-214.

Labrie, V., Duffy, S., Wang, W., Barger, S. W., Baker, G. B., and Roder, J. C. (2009). Geneticinactivation of D-amino acid oxidase enhances extinction and reversal learning in mice. Learn. Mem. $16,28-37$.

Laurent, V., and Podhorna, J. (2004). Subchronic phencyclidine treatment impairs performance of C57BL/6 mice in the attentional set-shifting task. Behav. Pharmacol. 15, 141-148.

Leeson, V.C., Robbins, T. W., Matheson, E. Hutton, S. B., Ron, M. A., Barnes, T. R. and Joyce, E. M. (2009). Discrimination learning, reversal, and set-shifting in first-episode schizophrenia: stability over six years and specific associations with medication type and disorganization syndrome. Biol. Psychiatry 66, 586-593.

Lewis, D. A., and Gonzalez-Burgos, G. (2006). Pathophysiologically based treatment interventions in schizophrenia. Nat. Med. 12, 1016-1022.

Mackintosh, N. J., McGonigle, B., Holgate, V., and Vanderver, V. (1968). Factors underlying improvement in serial reversal learning. Can. J. Psychol. 22, 85-95.

Meliska, C. J., Burke, P. A., Bartke, A., and Jensen, R. A. (1997). Inhibitory avoidance and appetitive learning in aged normal mice: comparison with transgenic mice having elevated plasma growth hormone levels. Neurobiol. Learn. Mem. 68, 1-12.
Miller, E. K., and Cohen, J. D. (2001). An integrative theory of prefrontal cortex function. Annu. Rev. Neurosci. 24, 167-202.

Murray, G. K., Cheng, F., Clark, L., Barnett, J. H., Blackwell, A. D., Fletcher, P. C., Robbins, T. W., Bullmore, E. T., and Jones, P. B. (2008). Reinforcement and reversal learning in first-episode psychosis. Schizophr. Bull. 34, 848-855.

O'Leary, T. P., and Brown, R. E. (2009). Visuo-spatial learning and memory deficits on the Barnes maze in the 16-month-old APPswe/PS1dE9 mouse model of Alzheimer's disease. Behav. Brain Res. 201, 120-127.

Pantelis, C., Barber, F. Z., Barnes, T. R. Nelson, H. E., Owen, A. M., and Robbins, T. W. (1999). Comparison of set-shifting ability in patients with chronic schizophrenia and frontal lobe damage. Schizophr. Res. 37, 251-270.

Papaleo, F., Crawley, J. N., Song, J., Lipska B. K., Pickel, J., Weinberger, D. R., and Chen, J. (2008). Genetic dissection of the role of catechol-O-methyltransferase in cognition and stress reactivity in mice. J. Neurosci. 28, 8709-8723.

Powell, C. M., and Miyakawa, T. (2006) Schizophrenia-relevant behavioral testing in rodent models: a uniquely human disorder? Biol. Psychiatry 59, 1198-1207.

Ragozzino, M. E., Wilcox, C., Raso, M. and Kesner, R. P. (1999). Involvement of rodent prefrontal cortex subregions in strategy switching. Behav. Neurosci. $113,32-41$.

Ranganath, C., Minzenberg, M. J., and Ragland, J. D. (2008). The cognitive neuroscience of memory function and dysfunction in schizophrenia. Biol. Psychiatry 64, 18-25.

Robbins, T. W. (2005). Synthesizing schizophrenia: a bottom-up, symptomatic approach. Schizophr. Bull. 31, 854-864.

Robbins, T. W., James, M., Owen, A M., Sahakian, B. J., McInnes, L., and Rabbitt, P. (1994). Cambridge Neuropsychological Test Automated Battery (CANTAB): a factor analytic study of a large sample of normal elderly volunteers. Dementia 5, 266-281.

Roberts,A.C.(2006). Primate orbitofrontal cortex and adaptive behaviour. Trends Cogn. Sci. 10, 83-90.

Rodefer, J. S., Murphy, E. R., and Baxter, M. G. (2005). PDE10A inhibition reverses subchronic PCP-induced deficits in attentional set-shifting in rats. Eur. J. Neurosci. 21, 1070-1076.

Rodefer, J. S., Nguyen, T. N., Karlsson, J. J., and Arnt, J. (2008). Reversal of subchronic PCP-induced deficits in attentional set shifting in rats by sertindole and a 5-HT(6) receptor antagonist: comparison among antipsychotics. Neuropsychopharmacology 33, 2657-2666.
Saura, C. A., Chen, G., Malkani, S., Choi, S. Y., Takahashi, R. H., Zhang, D., Gouras, G. K., Kirkwood, A., Morris, R. G., and Shen, J. (2005). Conditional inactivation of presenilin 1 prevents amyloid accumulation and temporarily rescues contextual and spatial working memory impairments in amyloid precursor protein transgenic mice. J. Neurosci. 25 , 6755-6764.

Schmitt, W. B., Deacon, R. M., Reisel, D., Sprengel, R., Seeburg, P. H., Rawlins, J. N., and Bannerman, D. M. (2004) Spatial reference memory in GluR-Adeficient mice using a novel hippocampal-dependent paddling pool escape task. Hippocampus 14, 216-223.

Schoenbaum, G.,Chiba,A.A., and Gallagher, M. (2000). Changes in functional connectivity in orbitofrontal cortex and basolateral amygdala during learning and reversal training. J. Neurosci. 20, 5179-5189.

Schoenbaum, G., Saddoris, M. P., Ramus, S. J., Shaham, Y., and Setlow, B. (2004) Cocaine-experienced rats exhibit learning deficits in a task sensitive to orbitofrontal cortex lesions. Eur. J. Neurosci. 19, 1997-2002.

Schoenbaum, G., and Shaham, Y. (2008). The role of orbitofrontal cortex in drug addiction: a review of preclinical studies. Biol. Psychiatry 63, 256-262.

Skelton, M. R., Ponniah, S., Wang, D. Z., Doetschman, T., Vorhees, C. V., and Pallen, C. J. (2003). Protein tyrosine phosphatase alpha (PTP alpha) knockout mice show deficits in Morris water maze learning, decreased locomotor activity, and decreases in anxiety. Brain Res. 984, 1-10.

Stack, C. M., Lim, M. A., Cuasay, K., Stone, M. M., Seibert, K. M., Spivak-Pohis, I., Crawley, J. N., Waschek, J. A., and Hill, J. M. (2008). Deficits in social behavior and reversal learning are more prevalent in male offspring of VIP deficient female mice. Exp. Neurol. 211, 67-84.

Stefani, M. R., Groth, K., and Moghaddam, B. (2003). Glutamate receptors in the rat medial prefrontal cortex regulate set-shifting ability. Behav. Neurosci. 117, 728-737.

Strekalova, T., Spanagel, R., Bartsch, D., Henn, F. A., and Gass, P. (2004). Stressinduced anhedonia in mice is associated with deficits in forced swimming and exploration. Neuropsychopharmacology 29, 2007-2017

Talpos, J. C., Winters, B. D., Dias, R., Saksida, L. M., and Bussey, T. J. (2009). A novel touchscreen-automated pairedassociate learning (PAL) task sensitive to pharmacological manipulation of the hippocampus: a translational rodent model of cognitive impairments in neurodegenerative disease. Psychopharmacology (Berl.) 205, 157-168.
Tan, H. Y., Callicott, J. H., and Weinberger, D. R. (2009). Prefrontal cognitive systems in schizophrenia: towards human genetic brain mechanisms. Cogn. Neuropsychiatry 14, 277-298.

Tonissoo, T., Koks, S., Meier, R., Raud, S., Plaas, M., Vasar, E., and Karis, A. (2006). Heterozygous mice with Ric- 8 mutation exhibit impaired spatial memory and decreased anxiety. Behav. Brain Res. $167,42-48$.

Varvel, S. A., and Lichtman, A. H. (2002). Evaluation of CB1 receptor knockout mice in the Morris water maze. J. Pharmacol. Exp. Ther. 301, 915-924.

Voikar, V., Rossi, J., Rauvala, H., and Airaksinen, M. S. (2004). Impaired behavioural flexibility and memory in mice lacking GDNF family receptor alpha2. Eur. J. Neurosci. 20, 308-312.

Waltz, J. A., and Gold, J. M. (2007). Probabilistic reversal learning impairments in schizophrenia: further evidence of orbitofrontal dysfunction. Schizophr. Res. 93, 296-303.

Wiedholz, L. M., Owens, W. A., Horton, R. E., Feyder, M., Karlsson, R. M., Hefner, K., Sprengel, R., Celikel, T., Daws, L. C., and Holmes, A. (2008). Micelacking the AMPA GluR1 receptor exhibit striatal hyperdopaminergia and 'schizophrenia-related' behaviors. Mol. Psychiatry 13, 631-640.

Zagreda, L., Goodman, J., Druin, D. P., McDonald, D., and Diamond,A. (1999). Cognitive deficits in a genetic mouse model of the most common biochemical cause of human mental retardation. J. Neurosci. 19, 6175-6182.

Zhuo, J. M., Prescott, S. L., Murray, M. E., Zhang, H.Y., Baxter, M. G., and Nicolle, M. M. (2007). Early discrimination reversal learning impairment and preserved spatial learning in a longitudinal study of Tg2576APPsw mice. Neurobiol. Aging 28, 1248-1257.

Conflict of Interest Statement: The authors declare that the research was conducted in the absence of any commercial or financial relationships that could be construed as a potential conflict of interest.

Received: 26 October 2009; paper pending published: 09 December 2009; accepted: 13 January 2010; published: 15 April 2010. Citation: Front. Neurosci. (2010) 4, 1: 19-28. doi: 10.3389/neuro.01.013.2010

Copyright (c) 2010 Brigman, Graybeal and Holmes. This is an open-access publication subject to an exclusive license agreement between the authors and the Frontiers Research Foundation, which permits unrestricted use, distribution, and reproduction in any medium, provided the original authors and source are credited. 